\title{
Correspondence
}

\section{Cleaner bunker fuel for ships in polar waters}

\section{Gilbert Jenkins}

1 Hamilton Drive, Sunningdale, Berks SL5 9PP.

\section{Received January 1992}

Recent oil spills in polar waters, coupled with possibilities of increasing maritime traffic in high latitudes, raise the question of whether polar ships' operators might be encouraged or required to use bunkering fuels that are environmentally safer. Most ships use a heavy residual fuel oil with specific gravity (SG) a litule lower than that of water, a $4 \%$ sulphur content and usually no saturated hydrocarbons (paraffins and cycloparaffins). When spilled in polar waters, this fuel takes longer to degrade than certain other fuels that are commercially available, and could thus be more damaging to wildlife.

Possible altemative fuels include (a) gas oil, highly aromatic grade; (b) gas oil, highly paraffinic grade: (c) waxy distillate, highly paraffinic; (d) kerosine, highly paraffinic; (e) naphtha, highly paraffinic; (f) liquid petroleum gas, completely paraffinic; (g) residual fuel oil, high SG (at $\left.60 / 60^{\circ} \mathrm{F} 1.05-1.10\right)$. Of these (a) to (f) are of lower SG and contain more volatile fractions which evaporate quickly: the last, of higher SG, would tend to stay in ruptured tanks in the event of an accident without fire. We do not know if these fuels would cause less damage overall to the environment if spilled in polar waters, but there is a good chance that they would cause less damage than the currently-used residual fuel oil.

Quantities of fuels required for use in polar waters are so small relative to the total availability of possible alternatives that supplies would be readily available. The cost of double-bottomed tankers required by US legislation is high. The cost of fuel substitution for vessels in polar waters would be negligible in comparison. A major oil company has in fact recently decided to stop using residual fuel oil in its tankers trading only in UK waters.

Surely it is now sensible to examine the possibilities of using safer fuels in polar waters.

\section{Reviews}

\section{SOUTHERN OCEAN ATLAS}

THE FRAM ATLAS OF THE SOUTHERN OCEAN. Webb, D., Killworth, P. D., Coward, A.C. and Thompson, S. R. 1991. Swindon, Natural Environment Research Council. $67 \mathrm{p}$, illustrated, hard cover. ISBN 185531036 8. $£ 100.00$. Obtainable from Library, IOSDL, Wormley, Godalming, Surrey GU8 5UB.

Published by NERC in association with the Institute of Oceanographic Science, this atlas, to quote from the foreword, is based on 'six years of assimilation of the archive of hydrographic data accumulated from oceanographic cruises over the last hundred years'. It differs from previous Southem Ocean atlases in treating the data, not as numbers to be analysed statistically, but '... as samples of a dynamical system which obeys the laws of nature', using computer modelling methods similar to those employed in weather forecasting. As the introduction explains, the model used is the UK Fine Resolution Antarctic Model (FRAM), which covers the Southern Ocean and neighbouring oceans. Depths are dealt with at 32 levels, ranging in thickness from $20.3 \mathrm{~m}$ near the surface to over $200 \mathrm{~m}$ deeper down. Horizontally the resolution is $0.25^{\circ} \mathrm{N}-S$ and $0.5^{\circ} \mathrm{E}-\mathrm{W}$, at $60^{\circ} \mathrm{S}$ providing a grid of $27 \mathrm{~km}$ in both directions - by any standard fine resolution indeed. Over the years this model has evolved to yield results which, even on the fine scale of ocean eddies and meanders, brings reality gratifyingly close. The data sets are available in computer-readable form from the British Oceanographic Data Centre.

The colour plates are in two groups. Part 1, made up of polar projections, includes bathmetry, potential temperature, salinity, current velocity and pressure at seven levels from surface to $3990 \mathrm{~m}$, temperature, salinity, velocity, depths and potential voticity at two density levels, and the Levitus temperature and salinity fields at $10.3 \mathrm{~m}$ and 1726 $\mathrm{m}$, which were used to initialize the model. Part 2 includes temperatures, salinities and cross-track velocities on a network of World Ocean Circulation Experiment hydrographic sections for each ocean, followed by brief explanatory notes. The final plate illustrates the transport stream function.

I am sure this is an excellent atlas of the Southern Ocean, and one capable of bringing a new level of visual understanding to those who can afford it. For whom is it intended? It is a large-format $(60 \times 43 \mathrm{~cm})$ atlas, ringbound under a plastic hinge, and lavishly produced. Several of the text pages are printed over a faint background of pack ice: the polar projections and sections are of generous size, larger than is essential for clarity, with much highquality white paper surrounding them. It smacks of an eyecatcher at public expense. The public (who have already subsidized its production) are asked to pay $£ 100$ 
for it: students and academics may order it at half price, but everyone pays $£ 12$ extra (overseas $£ 20$ ) for postage and packing. A less elegant atlas could have contained the same amount of information, indeed more, but cost far less: what a splendid atlas-with-text-and photographs, in more manageable size and shape, this could have made. Hard-pressed academic libraries may revolt at paying so much for what is essentially a picture book, when students will need more explanations to make sense of it, and involved academics will probably want access to the database itself. Full marks to the oceanographers who did the work: the faintest of cheers for unimaginative publishing. (Bernard Stonehouse, Scott Polar Research Institute, University of Cambridge, Lensfield Road, Cambridge CB2 1ER.)

\section{SOVIET ENVIRONMENTAL CONSCIOUSNESS}

ENVIRONMENTALMANAGEMENTINTHESOVIET UNION. Pryde, Philip R. 1991. Cambridge, Cambridge University Press (Cambridge Soviet Paperbacks 4). 314 p,illustrated. ISBN0 521409055 soft cover. $£ 10.95$, US $\$ 14.95$.

Philip Pryde is the western doyen of environmental problems in the former Soviet Union, noted for his Conservation in the Soviet Union (Cambridge, 1972), written when the USSR was of interest only to specialists and environmentalism was not yet fashionable. Pryde now distinguishes three phases of post-war environmental consciousness: the 'Baikal awakening' of the late 1960s and early 70 s, involving mostly writers and artists; the Chernobyl trauma from 1986 onwards, in which the general public came to see themselves as directly threatened; and the still-nascent 'perestroika awakening', the most crucial and delicate phase which he hopes will transform the consciousness of ministry officials and factory managers.

The book is comprehensive, leading the reader successively through topics like air, water, nature reserves and forests. The key areas, with a specifically Soviet twist, are nuclear power, and the relationship between the bureaucracy and public democratic activism. Pryde shows how nuclear energy is used almost exclusively in the densely populated areas west of the Urals far from the gas and oil of Siberia, and explores the many dilemmas of energy policy. He shows why the management flaws revealed by Chernobyl cannot be redressed so long as poachers still play the role of gamekeeper; and chronicles the response to this inadequacy, as the latent public concern has been transformed into citizens' action groups.

The Russian north has more industrial development (Noril'sk, Igarka, the Kola Peninsula) than the North in any other country. However, the North appears here as only one piece in a complex jigsaw: central Asian irriga- tion schemes interact with Arctic rivers; fallout from the Ukraine destroys reindeer pastures in Scandinavia. Thus, some major arctic crisis points are discussed only briefly or not at all, notably gas extraction in Yamal peninsula and atmospheric nuclear testing on Novaya Zemlya. But this is perhaps a correct perspective, an antidote to narrow regionalism: the Arctic can be understood only within the framework of the country as a whole, and this book is invaluable for putting the Russian North into this setting.

The author's long familiarity with the subject shows in his easy mastery of his enormous canvas. Sections have been contributed by Philip Micklin and Kathleen Braden, experts respectively on Soviet water management and forestry. The foreword is by Zeev Wolfson, who while still a Soviet bureaucrat blew the whistle with the publication of his The destruction of nature in the Soviet Union (White Plains, 1980) under the pseudonym Boris Komarov ('Boris Mosquito'). (Piers Vitebsky, Scout Polar Research Institute, Lensfield Road, Cambridge CB2 1ER)

\section{SIBERIAN BIBLIOGRAPHY}

SIBERIA AND THE SOVIET FAR EAST. Collins, David N (compiler). 1991. Oxford - Santa Barbara Denver, Clio Press (World Bibiliographical Series, vol. 127). $221 \mathrm{p}$, maps. ISBN 1-85109-157-2 hard cover. $£ 35.00$.

This is an annotated bibliography containing over 700 main entries. For each country or region, this series aims to 'express its culture, its place in the world, and the qualities and background which make it unique.' The publishers are to be congratulated on treating Siberia separately from the companion volumes entitled USSR and The Arctic as well as for entrusting the work to a noted historian of Siberia.

Apart from the obvious headings like 'Flora and fauna', 'Religion' or 'Languages', Collins gives us some characteristically Siberian ones like 'Energy, fuel and mineral resources', 'Environmental problems and protection' and 'Exile and imprisonment', as well as the interesting heading 'Literary works about Siberia'. The style of annotation allows several works to be discussed and compared under one entry. An oddity of this system is that sometimes an important source does not receive an entry of its own but is mentioned in discussion under a more feeble article. This is perhaps related to the problem of any compendium of English sources on the remoter parts of Russia: alongside the substantial works there are inevitably many digests or journalistic impressions. But the annotations are extremely helpful in guiding the reader to sources which meet his or her needs and the book is well indexed. (Piers Vitebsky, Scott Polar Research Institute, Lensfield Road, Cambridge CB2 1ER) 